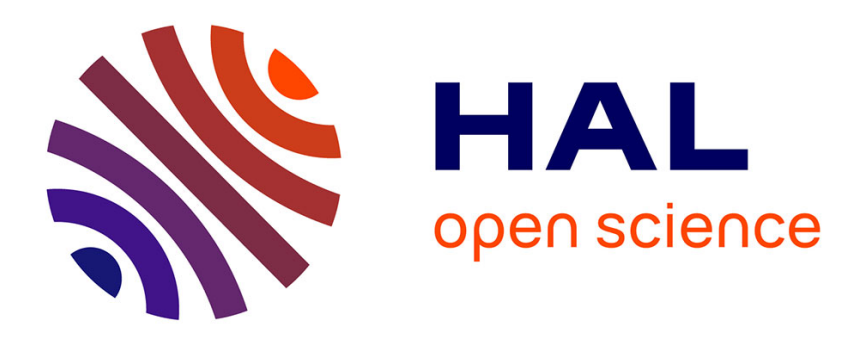

\title{
Neuropeptide-derived antimicrobial peptides from invertebrates for biomedical applications
}

\author{
M. Salzet
}

\section{To cite this version:}

M. Salzet. Neuropeptide-derived antimicrobial peptides from invertebrates for biomedical applications. Current Medicinal Chemistry, 2005, 12 (26), pp.3055-3061. 10.2174/092986705774933470 . hal00167311

\section{HAL Id: hal-00167311 https://hal.science/hal-00167311}

Submitted on 18 Aug 2007

HAL is a multi-disciplinary open access archive for the deposit and dissemination of scientific research documents, whether they are published or not. The documents may come from teaching and research institutions in France or abroad, or from public or private research centers.
L'archive ouverte pluridisciplinaire HAL, est destinée au dépôt et à la diffusion de documents scientifiques de niveau recherche, publiés ou non, émanant des établissements d'enseignement et de recherche français ou étrangers, des laboratoires publics ou privés. 
Neuropeptide-derived antimicrobial peptides from invertebrates for biomedical applications

\author{
Michel Salzet \\ Laboratoire de Neuroimmunologie des Annélides, \\ UMR CNRS 8017, IFR18, SN3, \\ Université des Sciences et Technologies de Lille \\ 59650 Villeneuve d'ascq, France
}




\begin{abstract}
Since the beginning of the XXth century, important medicine progress has led medical doctors to think that the end of devastating epidemics has arrived. In 1930, the discovery of sulfamids and penicillin opened a wide area of applications able to fight against bacterial infections. However, almost all antibiotics were baffled by the great ability to adaptation of bacteria (1) and the emergence of new bacterial agents, discovered with updated technologies. The living world is perpetually in co-evolution and since more than 3 billion years, bacteria have developed resistance mechanisms to overcome external aggressions. Thus, in the middle of the 80th, multi-resistant bacteria have appeared and disseminated out from hospitals. In this context, researches have been developed in order to find new antimicrobial substances to destroy such new types of bacteria. Thus, several groups have turned their focus on invertebrates which co-evoluate with human and have appeared on the planet since a long time. Evidence of new families of antimicrobial substances isolated from invertebrates different to the classical cationic peptide family i.e. dipeptides and anionic peptides have been given. Moreover, these molecules are also present in human and may serve in the innate immune response as an important survival strategy
\end{abstract}




\section{Introduction}

Hospitals worldwide have become literal breeding grounds for some of the most deadly and powerful bacteria. With the increased use of antibiotics, resistance has become more frequent, leaving healthcare professionals with ineffective therapies for bacterial infections. This conducts to the identification of new pathogenic micro-organisms ledding to huge discoveries, as for example many arthritogenic bacteria (Chlamidia, Yersinia, Salmonella and Shigella), which are implicated in chronical rhumatismalpathogenic affections [2-6]. The discovering of such new pathogenic microorganisms stimulate since a long time researches. The fascinating discovering has changed the classical conception of the simple relationship between host and bacteria in the direct pathogenesis, suggesting that some micro organisms can have an unknown role in some of affections presumably aseptic.

This results that patients may enter a hospital for heart surgery and develop an infection of the surgical site. Many of these hospital-acquired infections are caused by Staphylococcus aureus (S. aureus), a potentially fatal bacterium that can live for extended periods on medical devices such as intravenous (IV) lines and catheter tubes. Staphylococcal infections range from local skin infections to endocarditis (heart valve infection), osteomyelitis (bone infection), sepsis (bloodstream infection), pneumonia and surgical-site infections in hospitalized patients [2-6]. By 1982 only $10 \%$ of $S$. aureus strains were susceptible to penicillin. In U.S. hospitals from 2\% in 1975 to $35 \%$ in 1996 are become resistant to methicillin. The proportion of methicillin-resistant S. aureus (MRSA) has increased significantly. It is now estimated that about half of all S. aureus strains at many medical institutions are resistant to methicillin.

In the same bacterial family, methicillin-resistant $S$. epidermidis (MRSE) also compromises patient health. This organism, found primarily on skin tissue, was once considered a non-threatening contaminant. Now, it has been established as a leading cause of hospital-acquired bloodstream infections. More than $80 \%$ of S. epidermidis isolates in U.S. hospitals are methicillin resistant, and recent studies have found resistance to quinolones, cephalosporins and vancomycin. The emergence of $S$. epidermidis as a pathogen has been fuelled by the widespread use of catheters, prosthetic joints, valves and other invasive medical devices, and is a growing concern, particularly for immuno-compromised cancer patients.

Vancomycin is often used as the antibiotic of last resort for treating $S$. aureus and other bacterial infections, but not for long. This powerful antibiotic is now ineffective against many enterococcal infections. Vancomycin-resistant enterococci (VRE), for example, have developed resistance to all known antibiotics as a result of both successful mutations and the receipt of DNA from other drug-resistant bacteria. The US Centers for Disease Control and Prevention (CDC) in Atlanta, Georgia, reported a twenty-fold increase in the percentage of hospital-acquired enterococci found to be resistant to the drug vancomycin from January 1989 to March 1993. In fact, the mortality rate associated with VRE bloodstream infections has been estimated at $55 \%$.

Vancomycin is frequently used to treat bacteria that are resistant to all other antibiotics. Consequently, the emergence of vancomycin resistance among enterococci may accelerate the spread of vancomycin-resistant genes among other bacteria, eventually limiting the usefulness of this drug and leaving healthcare professionals without options for fighting bacterial diseases. In April 1997, the CDC reported the alarming emergence of S. aureus strains that show intermediate levels of resistance to vancomycin. The recent appearance of 
these strains in Japan and the U.S. suggests the high probability that strains of S. aureus completely resistant to vancomycin may soon emerge.

Thus, the discovery of new strain of bacteria implicated in chronically affections, justify our pathogenic and therapeutic conceptions that require natural antibacterial defences.

The development of new antibiotic compounds, originating from natural resources for drug development is a promising research territory. With their high number of species and representatives in all ecological niches, insects are the largest (80\% of all fauna) and widespread group within the Animal Kingdom. Invertebrates such like insects have developed a battery of natural antibacterial peptides $e . g$. defensins, cecropins [7, 8] as innate response to bacteria. Most of these peptides are conserved in course of evolutions such like defensins or cryptidins, peptides found in human intestine [9-13]. Moreover, new antibacterial peptides have recently been identified in glandular cells of amphibian skin (magainins, dermaseptins..), fishes, most classes of invertebrates and plants reflecting the universal characters of such natural defences [14-17]. The used of these informations coming from invertebrates can be an useful tools for caring septic diseases like Heart failure, the Crohn disease or reactional arthritis [1-6]. Moreover, since these last 15 years, several antibacterial peptides have also been identified in mammals particularly in secretions of immune cells or genital, digestive and intestinal epithelia tracts and skin of human [19-21] Secretory granules from adrenal medullary chromaffin cells contain a complex mixture of low molecular mass constituents, such as catecholamines, ascorbate, nucleotides, calcium and several water-soluble peptides and proteins [22-25]. These components are released into the circulation in response to splanchnic nerve stimulation. Relatively large amounts of pro-enkephalin-A and chromogranin-derived peptides are also found. Metz-Boutique's group has shown in bovine that antibacterial activity is present within the intragranular chromaffin granule matrix and the extracellular medium following exocytosis [22-25]. These peptides inhibit the growth of Gram-positive bacteria (Micrococcus luteus and Bacillus megaterium) at micromolar concentrations. In addition, antibacterial assays on soluble chromaffin granule material, recovered from HPLC, indicate the presence of several other endogenous peptides with potent antibacterial activity against Gram-positive and -negative bacteria. These new antibacterial peptides, derived from chromogranin- and pro-enkephalin-A precursors, are stored with catecholamines and released during stress [22-25]. Bactericidal activities of the chromogranin- or pro-enkephalin-A-derived peptides are modulated by the degree of maturation of the precursor and by the presence of post-translational modifications (phosphorylations, O-glycosylation). Natural processing of these precursors at the $\mathrm{N}$ - and Cterminals generates most of these peptides [22-25].

Recently, since the discovering of panoply of new antibacterial peptides in invertebrates [26] (Table 1), the use of such animals in this research field is in constant progress. In fact, invertebrates had developed an adapted system of defence to fight and destroy efficiently pathogen agents. Invertebrates fight against micro organisms in synthesizing and in releasing in same time a battery of antibacterial peptides during septic infections. Thus, the repeated discovery of antibiotic molecules present in both Vertebrates and Invertebrates reflect the presence of a rapid chemical mechanism of defence against bacteria, the innate immune response co-existing with the specific one [26]. Moreover, knowing the fact that a bacteria is multiplied 50 fold faster than a B cell and that these antimicrobial peptides diffuse quicker and easier than antibodies, this shows that this type of economic molecules with a broad spectrum allow a fast defensive response superior to 
microorganisms multiplication. These peptides appear perfectly adapted to offer such efficacious defensive line against infectious agents.

\section{Maggots Therapy: small antimicrobial peptides peptides : the neurodocrine link}

When we think about saprophytic insects, which live during their complete larval development in faces or decomposing organic material the question raises how these animals can live in an environment, which is so rich in pathogen micro-organisms. Insects mount a very effective humoral and cellular response to invasive microorganisms, which differs from the defense mechanisms, known from in vertebrates. A specific cell mediated and acquired immunity does not appear to exist in insects. Phagocytosis of bacteria or a melanotic encapsulation response to metazoan parasites is considered to be an important defense mechanism [26]. Insects also respond to bacterial invasion with the synthesis of an array of antibacterial peptides. In recent years these compounds have been studies extensively and classified into distinct families (for reviews on the cecropins, attacins, diptericins, defensins and proline and glycine rich compounds, [27]).

The beneficial effect of fly larvae for wounds has been known for a very long time. In the $19^{\text {th }}$ century, Baron Larrey (physician-in-chief in Napoleon's army) and Dr. Joseph Jones (medical officer during the American Civil War) reported that soldiers, who remained wounded for several days in the battle field, did not die thanks to the healing effects of maggots (larvae of dipterans) which had intruded the open wounds [28]. Maggot therapy was extensively used in the 1930's and 1940's in more than 300 hospitals in the USA alone for the treatment of suppurative skin infections, but was later abandoned with the introduction of antibiotics and the use of aggressive surgical debridements. Since the mid 1990's the method was re-introduced not only in the USA, but also in Europe, i.e. University Hospital Antwerp [29]. Maggot therapy [Fig. 1] is the salvage therapy for cases where the poor blood supply to the deep wounds and subsequent inability of immunological mediators and systemic antibiotics to reach the infected areas, prevent the healing process (patients with diabetic feet and pressure ulcers, [30]). In such cases, antibiotic treatment, surgical debridement and drainage fail to stop the progressive tissue destruction [31-34].

Maggots are naturally exposed to an infected environment. Such ongoing exposure causes evolutionary pressure to develop a unique antibacterial mechanism, including the secretion of substances that protect them against highly pathogenic bacteria. As mentioned above several antibacterial peptides have been identified in the animal kingdom [26]. These antibacterial peptides usually exceed $3 \mathrm{kDa}$ and some of them are at developed by companies i.e. Intrabiotics, Magainin Pharmaceutical Inc, Micrologix Biotech Inc, Entomed [26]. Most of the known high molecular weight peptides are their overall cationic charge, which facilitates membrane binding, upon which they organize into $\alpha$-helix and form pores in the cell membrane. However, these characteristics also make these antibacterial agents potentially cytotoxic for eukaryotic cells as well [Table 1].

It is necessary to focus on low-molecular weight compounds, since these are generally more stable and effective. Interest in low-molecular antibacterial compounds has increased during recent years because of the major health problems caused by antibiotic resistance in the last few years in Europe. Two small molecular weight antibacterial compounds have recently been identified by Leem et al., [35,36]: the 573 Da N-B-Alanyl-5-S-glutathionyl-3,4dihydroxye-Phe has been identified in adult flies (Sarcophaga peregrina) and the $148 \mathrm{Da}$ phydroxycinnamaldehyde (MW: 148) from larva of the saw fly, Acantholyda parki S. Schoofs 
and colleagues have recently demonstrated that $\beta$-Ala-Tyr (MW:252; [Fig. 2]), which was identified in larvae of the gray flesh fly [36-40] displays potent antibacterial activity in maggots. From the same species, other antibacterial compounds were purified [38]. They have a molecular weight of 224 and $243 \mathrm{Da}$, respectively [38]. Their structures were identified by ESI-Qq-TOF mass spectrometry (MS-MS-mode) and correspond to 3-hydroxykynurenine and dehydro-Ala-Arg, respectively [28]. All these peptides have in common to exhibited paralytic activity when injected into adult insects [38]. No cytotoxic effect could be observed in vitro on insect neuronal cells [38]. When applied to rat C6 glioma cells, rat primary neurons or human neuroblastoma cell lines IMR32 and SHSY5Y, no cytotoxic effect of $\beta$-AY was detected up to $10 \mathrm{mM}$ concentrations [38]. Intraspinal injection in rats gave no significant effect at concentrations as high as $198 \mathrm{mM}$ [38]. However, the effects of $\beta$-AY application in vertebrates must be further examined. Besides for clinical applications, $\beta$-AY may be used as antimicrobial additive to cell culture growth media, or as preservative in foods, pharmaceuticals, cosmetics and other products susceptible to microbial deterioration.

The exact mode of action of p-hydroxycinnamaldehyde and $\beta$-AY has not been elucidated as yet. However, the cytotoxicity of hydroxylated phenolic compounds and their oxidation products has been long recognised and is thought to be due to the production of free radicals [38] and to their inhibitory interactions with proteins in general. The inhibitory effect of such compounds on micro-organisms is, among other things, dependent on the rate of hydroxylation [38]. The main effectors of activity are quinones, which are aromatic rings with two ketone substitutions. Hydroxylated amino acids can be converted into quinones by phenoloxidases such as tyrosinase [Fig. 3]. The bactericidal effect of $\beta$-AY at concentrations higher than the MIC value, was rapid for bacterial cells that are suspended in microbial growth medium but not for bacterial cells in phosphate buffer. The most likely explanation is that only actively metabolizing cells are sensitive to the bactericidal effect of $\beta$-AY. Rather, the observation that growing cells are more sensitive, suggests that $\beta$-AY may interact with a vital metabolic process.

The biochemical characterization of low molecular weight antibacterial compounds in insect larvae will reveal a new class of antibacterial substances, with potential to serve as lead compounds for a new brand of antibiotics. In fact, although several interesting antimicrobial compounds have meanwhile reached the stage of clinical trials [www.phrma.org], possible applications are often limited to topical treatments. Being mostly peptidergic in nature, these natural antimicrobial compounds are susceptible to proteolytic breakdown by proteases, encountered during internal digestion in the gastro-intestinal tract or transport in the bloodstream, and consequently have too limited half-life upon systemic application. Moreover, most antimicrobial peptides have a high content of Lys and Arg, which are the main target of trypsine-like proteases. As such, it is important to identify smaller, perhaps even non-peptidergic substances with antimicrobial activity, as these can be expected to be more stable. Being small, they are also more likely to be suitable for production by chemical synthesis, thus bypassing the need for more expensive and labour intensive recombinant expression systems.

\section{Leeches : antibacterial peptides for Cardiovascular diseases diagnosis}

Haematophagous leeches are ecto-parasites and have a long life cycle e.g. 10 years for Hirudo medicinalis or 30 years for Heamentheria officinalis [41] which defend themselves against bacteria attacks after injury or after a blood meal. Regarding their life cycle they appear to have an immune system very powerful. We recently demonstrate that these animals 
have a high anti-microbial panoply, some are bore on neuropeptide precursors [42]. These precursors are processed into active neuro- and antibacterial peptides. We found in leeches 15 min after bacteria infection enkephalins and panoply of antibacterial peptides such like enkelytin-like, peptide B-like [42] and chromacin-like peptides [43] [Fig. 4]. These molecules implicated in innate immune defense initiate and reinforce the inflammation immune response [44]. Moreover, they present sequence identity with vertebrate antibacterial molecules, we recently found in human plasma after coronary cardiology by-pass [45]. In fact, during coronary cardiology by-pass, time-course experiments showed the presence of a new family of antibacterial peptides i.e. serine rich, bi-phosphorylated and related to enkelytin, peptide B, fribinopeptide A and the apolipoprotein CIII [Table 2] and opioids (Methionine-Enkephalin and Methionine-Enkephalin Arg Phe) in plasma after surgery [44, 45]. This suggests a new processing of these neuropeptide precursors in immunocytes or endothelial cells, not yet known.

Recent data in human have shown that that an injury to the endothelium might initiates and promotes the atherosclerotic process and this 'response to injury' concept is now widely accepted [46]. Information obtained in the past few years concerning the various atheromatous cellular components in spontaneous atherogenesis pointed out, at earlier stage, an accumulation of monocyte-derived macrophages, foam cell formation and interactions among lipoproteins, lymphocytes and other immune mediators, the process ultimately involving an inflammatory state in which macrophages and $\mathrm{T}$ lymphocytes play a major role [47-49]. In addition, it has been suggested that 'plaque activity' and the function of the cellular components can be a more important determinant of the clinical manifestations of atherosclerosis than is the percentage of stenosis of arterial lesions [50]. Antigen within the plaque may enhance the immunological activity and therefore the atherogenic inflammation. Suggested antigenic stimuli include modified cholesterol-rich lipoproteins [51], but also exogenous pathogens as bacteria. Indeed, over the past decade, increasing evidence obtained from epidemiological studies has accumulated suggesting a role for infectious agents in the genesis of atherosclerosis: Helicobacter pylori [52, 53], Chlamydia pneumoniae [54], Pneumococcal endocartis [55], coagulase-negative staphylococci [56], Streptococcus pneumoniae [57]. These data even led to the development of adequate clinical trials to evaluate the putative protective effect of antibiotics in patients suffering a coronary artery disease $[58,59]$. In contrast, two prospective studies, involving a large cohort of white male physicians, did not confirm any association between the risk of myocardial infarction and prior infection with cytomegalovirus, herpes simplex virus, or Chlamydia pneumoniae [60, 61].

As recently reviewed by Epstein and Zhu [62], these conflicting results may be largely due to the design of the studies. Most of the significant associations between bacterial infection and cardiovascular diseases were reported in retrospective studies in which information of a prior exposure to the suspected risk factor is obtained after the occurrence of the disease. Such a design does not allow taking into account for time-delay between exposure and disease onset, a notion that could be determinant in some cases. From this point of view, prospective studies offer additional information concerning the physiopathological process. Another criticism concerns the representativeness of the population samples. Indeed, in the prospective study, the absence of association between prior infection and MI was shown in a large, but extremely homogeneous, cohort of physicians. Compared to the general population, this cohort strongly differs in terms of socio-economic status and knowledge of other risk factors, a significant bias reducing the possible generalisation of the conclusions. The third important aspect that may explain conflicting results may be the end points. Significant 
associations between prior infection and the presence of atherosclerotic lesions do not imply similar associations with acute ischemic phase of the disease, such as MI or stroke. Indeed, the disruption of the atherosclerotic plaque, the most frequent critical step leading to ischemia, essentially depends on the structure of the lesion at the time of onset, in which initial bacterial infection probably poorly interferes. The final argument should be that, in most of these studies, prior infection was assessed by an immunological diagnosis implicating the activation of an advanced but late mechanism of defence. It may be postulated that other molecules, such as antibacterial peptides, should be more sensitive and earlier markers of the risk of CAD related to prior infection than antibodies. Indeed, data obtained from Invertebrates demonstrated the existence of an innate immune response based on short peptides developing an antibacterial activity. This process is suspected to constitute a rapid chemical mechanism of defence against infection, also characterised in humans.

\section{ACKNOWLEDGEMENTS}

This work was supported in part by the MNERT, the CNRS, the FEDER and the Conseil Régional de la région Nord-Pas De Calais and génopole of lille. The author would like to thank the referees for their recommendations.

\section{References}

1. Novak, R., Henriques, B., Charpentier, E., Normak, S., Tuomanen, E. Letters to Nature, 1999, 399, 590.

2. Hammer, M., Witte, T., Mugge, A., Wollenhaupt, J., Laas, J., Laszig, R., Zeidler, H. $C$ J. Rheumatol., 1994; 21, 552.

3. Wong, Y., Thomas, M., Tsang, V., Gallagher, P.J., Ward, M .E. J. Am. Coll. Cardiol., 1999, 33, 152.

4. Sinisalo, J., Mattila, K., Nieminen, M.S., Valtonen, V., Syrjala, M., Sundberg, S., Saikku, P. J. Antimicrob. Chemother., 1998;41; 85.

5. Roder, B.L., Wandall, D.A., Frimodt-Moller, N., Espersen, F., Skinhoj, P., Rosdahl, V.T. Arch. Intern. Med., 1999, 159, 462.

6. $\quad$ Lindberg, J., Prag, J., Schonheyder, H.C. Scand. J Infec. Dis., 1998,30, 469.

7. Hoffmann, J.A., Reichart, J.M., Hetru, C. Current opinion in Immunol., 1996, 8, 8.

8. Miester, M., Lemaitre, B., Hoffman, J. Bioassays, 1997, 19,1019.

9. Mallow, E.B., Harris, A., Salzman, N., Russell, J.P., De Berardinis, R.J., Ruchelli, E., Bevins, C.L. J. Biol. Chem., 1996; 271, 4038.

10. Ouellette, A.J., Hsieh, M.M., Nosek, M.T., Cano-Gauci, D.F., Huttner, K.M., Buick, R.N., Selsted, M.E. Infect. Immun., 1994, 62, 5040.

11. Porter, E.M., Van Dam, E., Valore, E.V. Infect. Immun., 1997, 65, 2396.

12. Lencer, W.I., Cheung, G., Strohmeier, G.R., Currie, M.G., Ouellette, A.J., Selsted, M.E., Madara, J.L. Proc. Natl. Acad. Sci. USA, 1997, 94, 8585.

13. Ghosh, J.K., Shaool, D., Guillaud, P., Ciceron, L., Mazier, D., Kustanovich, I,. Shai, Y., Mor, A. J. Biol. Chem., 1997,272, 31609.

14. Vouille, V., Amiche, M., Nicolas, P. FEBS Lett., 1997, 91, 27.

15. Hancock, R.E.W. Lancet, 1997, 349, 418 .

16. Boman, H.G. Scand. J. Immunol., 1998, 48, 15.

17. Hoffman, J.A. Curr. Opin. Immunology, 1995, 7, 4. 
18. Stenger, S., Hanson; D.A., Teitelbaum; R., Dewan; P., Niazi; K.R., Froelich; C.J., Ganz; T., Thoma-Uszynski; S., Melian; A., Bogdan; C., Porcelli; S.A., Bloom; B.R., Krensky, A.M., Modlin; R.L .Science, 1998, 282, 121

19. Nissen, J.B., Lund, M., Stengaard-Pedersen, K., Kragballe, K. Arch. Dermatol. Res., 1997, 289, 265.

20. Schröder, J-M. Biochem. Pharmacol., 1999, 57, 121.

21. Borregaard, N., Elbach, P., Ganz, T., Garred, P., Svejgaard, A. Imm. Today, 2000, 68, 68.

22. Brogden, K.A., Guthmiller, J.M., Salzet, M., Zasloff, M. Nat. Immunol., 2005, 6, 558.

23. Goumon, Y., Strub, J.M., Moniatte, M., Nullans, G., Poteur, L., Hubert, P., Van Dorsselaer, A., Aunis, D, Metz-Boutigue, M.H. Eur. J. Biochem., 1996, 235, 516.

24. Strub, J.M., Garcia-Sablone, P., Lönning, K., Taupenot, L., Hubert, P., Van Dorsselaer, A., Aunis, D.; Metz-Boutigue, M.H. P. Eur. J. Biochem., 1995, 229, 356.

25. Strub, J.M., Goumon, Y., Lugardon, K., Capon, C., Lopez, M., Moniatte, M., Van Dorsselaer, A., Aunis, D., Metz-Boutigue, M.H. J. Biol. Chem., 1996, 271, 28533.

26. Vizioli, J., Salzet,M. Trends Pharma. Sci., 2002,23,494

27. Hétru, C., Hoffman, D., Bulet, P. In Molecular Mechanisms of Immune Respones in Insects, Chapman and Hall, Eds., London., 1998, pp. 40-66.

28. Chernin, E. South Med. J., 1986, 79, 1143.

29. Thomas, S., Jones, M., Shutler, S., Jones, S. J.Wound Care, 1996, 5, 60.

30. Sherman, R.A. Int. J. Low. Extrem. Wounds, 2002, 1, 135.

31. Sherman, R.A, Wyle, F., Vulpe, M. J. Spinal Cord Med., 1996, 18, 71.

32. Sherman, R.A., Pechter, E.A. Med.Vet. Entomol., 1988, 2, 225.

33. Sherman, R..A, My-Tien, T., Sullivan, R. Arch. Dermatol., 1996, 132, 254.

34. Mumcuoglu, K.Y., Ingber, A., Gilead, L., Goldfarm, A., Lipo, M., Steisman, B., Turkeltaub, I., Bichucher, C; Friedman, D;, Shulman, H., Hamburger, E;, IoffeUspenky, I;, Miller, J;, Galun, R., Raz, I. Diabetes care, 1998, 21, 2030.

35. Leem, J.Y., Jeong, I.J., Park, K.T., Park, H.Y. FEBS Lett., 1999, 442, 53.

36. Leem, J.Y., Nishimura, C., Kurata S., Shimada I., Kobayashi A., Natori, S. J. Biol. Chem., 1996, 271, 13573.

37. Chiou, S.J., Cerstiaens, A., Kotanen, S.P., De Loof, A., Schoofs L. J. Insect Physiol., 1998, 44, 405.

38. Meylaers, K., Cerstiaens, A., Vierstraete; E., Baggerman; G., Michiels, C.W., De Loof, A., Schoofs, L. Curr Pharm Des., 2003, 9, 159

39. Kyrikou, I., Grdadolnik, S.G., Tatari, M., Poulos, C., Mavromoustakos, T. J. Pharm. Biomed. Anal., 2003, 31, 713.

40. Chiou, S.J., Kotanen, S.P., Cerstiaens, A., Daloze, D., Pasteels, J.M., Lesage, A., Drijfhout, J.W., Verhaert, P., Dillen, L., Claeys, M., De Meulemeester, H., Nuttin, B., De Loof, A., Schoofs, L. Biochem. Biophys. Res. Com., 1998, 246, 457.

41. Sawyer, R.T. Leech Biology and behavior. Clarendon Press, Oxford, 1998.

42. Tasiemki, A., Salzet, M., Benson, H., Fricchione, G.L., Bilfinger, T.V., Aunis, D., Metz-Boutigue, M.H., Goumon, Y., Stefano, G.B. J. Neuroimmunol., 2000, 109, 228.

43. Salzet, M., Stefano, G.B. Neuroendocrinol. Lett., 2003, 24, 227.

44. Tasiemski, A., Hammad, H., Vandenbulcke, F., Breton, C., Bilfinger, T.V., Pestel, J., Salzet, M. Blood, 2002, 100, 553. 
45. Tasiemski, A, Verger-Bocquet, M, Cadet, M, Goumon, Y, Metz-Boutigue, MH, Aunis, D, Stefano, GB, Salzet, M. Mol. Brain Res., 2000, 76, 237.

46. Stefano, G.B., Salzet, B., Fricchione, G.L. Immunol.Today, 1998, 19, 265.

47. Ross, R. Nature, 1993, 362, 801.

48. Hansson, G.K. Atherosclerosis, 1989, 9, 567.

49. Ip, J.H., Fuster, V., Badimon, L., Badimon, J., Taubman, M.B., Chesebro, J.H., J. Am. Coll. Cardiol., 1990, 15, 1667.

50. Azar, R.R., Waters, D.D. Am. Heart. J., 1996, 132, 1101.

51. Steinberg, D., Parthasarathy, S., Carew, T., Khoo, J.C., Witztum, J.L. N. Engl. J. Med., 1989, 320, 915.

52. Mendall, M.A., Goggin, P.M., Molineaux, N., Levy, J., Toosy, T., Strachan, D., Camm, A.J., Northfield, T.C. Br. Heart. J., 1994, 71, 437.

53. Martin-de-Argila, C., Boixeda, D., Canton, R., Gisbert, J.P., Fuertes, A. Lancet, 1995, 346, 310.

54. Danesh, J., Collins, R., Peto, R. Lancet, 1997, 350, 430.

55. Lindberg, J., Prag, J., Schonheyder, H.C. Scand. J. Infect. Dis., 1998, 30, 469.

56. Huebner, J., Goldmann, D.A. Annu. Rev. Med., 1999, 50, 223.

57. Lindberg, J., Fangel, S. Scand. J. Infect. Dis., 1999, 31, 409.

58. Gurfinkel, E., Bozovich, G., Daroca, A., Beck, E., Mautner, B. Lancet, 1997, 350, 404.

59. Gurfinkel, E., Bozovich, G., Beck, E., Testa, E., Livellara, B., Mautner, B. Eur. Heart. J., 1999, 20, 121.

60. Ridker, P.M., Hennekens, C.H., Stampfer, M.J., Wang, F. Circulation, 1998, 98, 2796.

61. Ridker, P.M., Kundsin, R.B., Stampfer, M.J., Poulin, S., Hennekens, C.H. Circulation 1999, 99, 1161.

62. Epstein, S.E., Zhu, J.Circulation, 1999, 100, 1366.

63. Tasiemski, A., Vandenbulcke, F., Mitta, G., Lemoine, J., Lefebvre, C., Sautiere, P.E., Salzet, M. J. Biol. Chem., 2004, 279, 30973. 


\section{Table 1 -antimicrobial peptides from invertebrates (up date from [26])}

Structure

\section{Cationic peptides}

\section{Linear alpha-helix peptides cecropins metazoa}

\section{Linear peptides rich in certain amino-acid}

Pro-rich drosocin, metchnikowins

pyrrhocoricin, metalnikowins

bugs

$\begin{array}{ll}\text { lumbricins } \\ \text { Gly-rich } & \text { diptericins, attacins }\end{array}$

Armadillins

Arg-rich perinerin

His-rich theromyzin

Single disulfide bridge

thanatin

Two disulfide bridges

Aranacins

tachyplesin II

androctonin

Three disulfide bridges

defensins

penaeidins

More than three disulfide bridges

tachycitin
drosomycin
gambicin
helyomicins
theromacin
ASBF

Cyclic peptides

Others

Jasplakinolide, cyclo-(glycyl-L-prolyl-L-glutamyl),

horseshoe crab

fruit fly

mosquitoes

lepidopteran

leeches

nematodes

sponges

cyclo-(glycyl-L-seryl-L-prolyl-L-glutamyl) bacteria

bacteria, fungi

bacteria

bacteria

bacteria

fungi

bacteria

bacteria, fungi

bacteria

bacteria, fungi, virus

bacteria, fungi

bacteria, fungi, protozoa

bacteria, fungi

bacteria, fungi

fungi

bacteria, fungi, protozoa

bacteria, fungi

bacteria

bacteria

bacteria, fungi 
Anionic peptides

Neuropeptide derived

$$
\begin{aligned}
& \text { enkelytin, leech, mussel, bacteria } \\
& \text { peptide B leech, mussel, bacteria }
\end{aligned}
$$

Aromatic dipeptides

$\begin{array}{lll}\text { p-hydroxycinnamaldehyde } & \text { saw fly } & \text { bacteria, fungi } \\ \text { N-ß-Alanyl-5-S-glutathionyl- } & \text { flesh fly } & \text { bacteria, fungi } \\ \begin{array}{l}\text { 3,4-dihydroxye-Phe } \\ \beta \text {-alanyl-tyrosine }\end{array} & \text { flesh fly } & \text { bacteria, fungi }\end{array}$

Oxygen- binding protein derived

hemocyanin derived

hemerythrin

hemoglobin derived

containing metal ion

Hedistin

$\begin{array}{ll}\text { shrimps } & \text { bacteria } \\ \text { annelids } & \text { bacteria } \\ \text { tick } & \text { bacteria }\end{array}$

polychaeta bactertia

Table 2 : New antibacterial peptides isolated in human plasma from people suffering of cardiovascular disease

\section{Peptides}

Fibrinopeptide 20-35

Apolipoprotein 21-57

Peptide B

Enkelytin

$\begin{array}{cc}\text { Mass (kDa) } & \mathbf{p H i} \\ 3116,3 & 4,53 \\ 3810,5 & 4,49 \\ 3616,9 & 4,18 \\ 3313,6 & 3,98\end{array}$

Figure Legends
Sequences

DSGEGDFLAEGGGVRGPRVVERHQSACKDS

SEAEDASLLSFMQGYMKHATKTAKDFTALSSVQES

FAEALPSDEEGESYSKEVPEMEKRYGGFMRF

FAEALPSDEEGESYSKEVPEMEKRYGGFM

Figure 1: Maggot Therapy for diabetical foot woods (Acker, 1999)

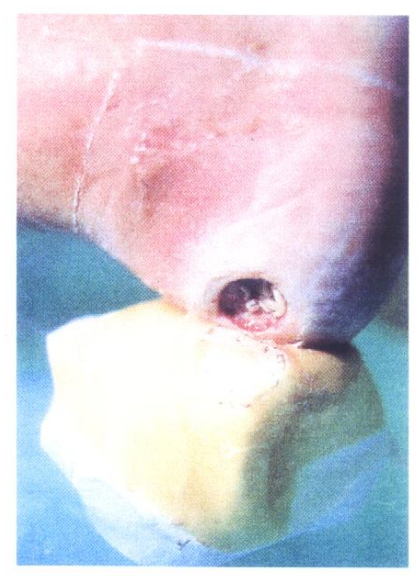


Figure 2 : Structural formula of antimicrobial compounds with low molecular mass, isolated from insects.

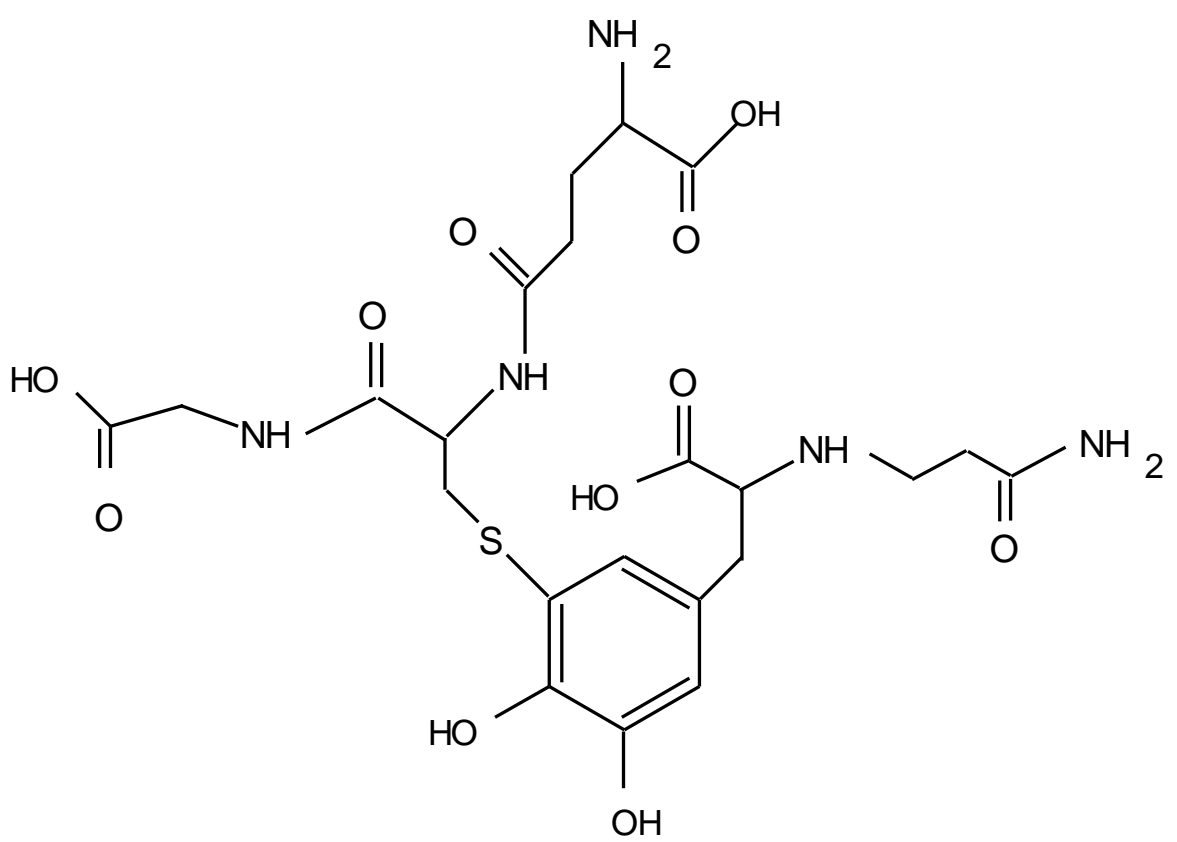

N- $\beta$-alanyl-5-S-glutathionyl-3.4-dihydroxyphenylalanine

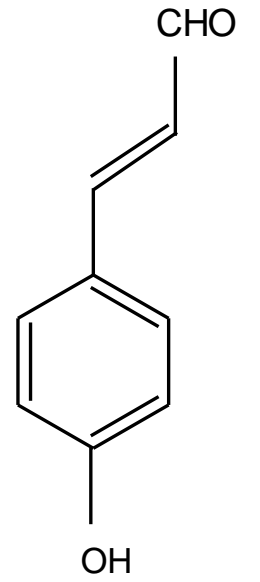<smiles>NCCC(=O)NC(Cc1ccc(O)cc1)C(=O)O</smiles>

p-hydroxycinnamaldehyde

$\beta$-alanyl-L-tyrosine 
Figure 3: Conversion of tyrosine to quinone by tyrosinase (from [38]).

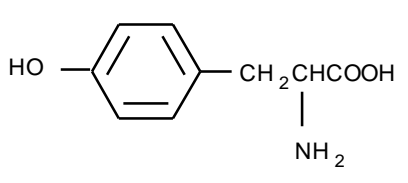

tyrosine

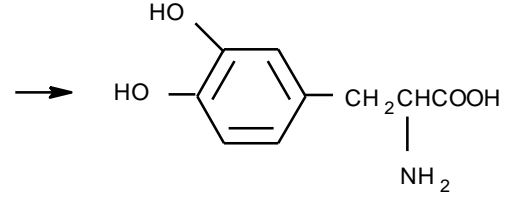

dopa

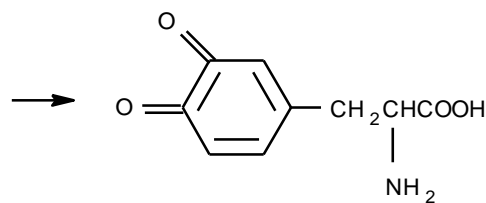

o-quinone

Figure 4: Antimicrobial (theromacine, theromyzine, enkelytine) peptides found in leech coccons [63] inset photograph represents a Theromyzon tessulatum with cocoons.

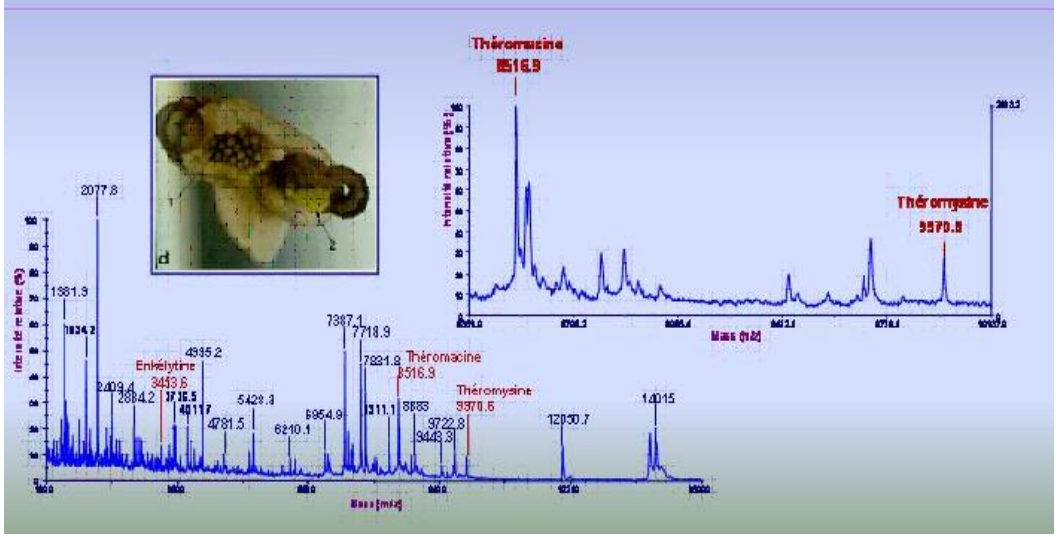

